\title{
The Effect of Physical Activity and Red Dragon Fruit (Hylocereus polyrhizus) in Red Blood Cell and Hemoglobin in Trained People
}

\author{
Novita Sari Harahap $^{1 *}$, Nurhayati Simatupang ${ }^{1}$, Suprayitno Suprayitno ${ }^{2}$ \\ ${ }^{1}$ Department of Sports Sciences, Faculty of Sports Sciences, Universitas Negeri Medan, Medan, North Sumatra, Indonesia; \\ ${ }^{2}$ Department of Physical Education and Health Recreation, Faculty of Sports Sciences, Universitas Negeri Medan, North \\ Sumatra, Indonesia
}

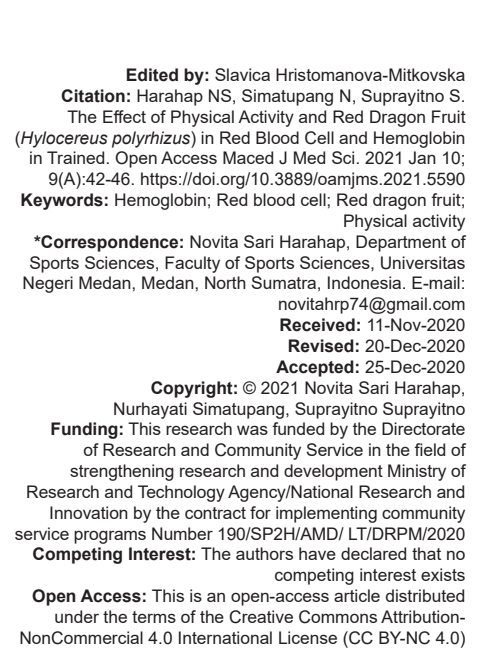

\begin{abstract}
BACKGROUND: Physical fitness depends on hematological parameters such as red blood cells and hemoglobin. Hemoglobin is needed in adequate quantities in trained athletes, especially in endurance sports. The effects of antioxidant supplementation are not yet fully known whether the body's natural antioxidants that act as a defense system can overcome the increase in free radicals during physical exercise or whether additional supplements are
\end{abstract} needed.

AIM: The purpose of this study was to find out the effect of physical activity and consumption of red dragon fruit on red blood cells and hemoglobin in trained people.

METHODS: The subject of the study was 20 people, male, trained, divided into two groups randomly, each consisting of 10 people, namely, Group 1 (PA): A group that was given physical exercise and obtained a placebo; Group 2 (PA+RDF): A group was assigned physical activity and given red dragon fruit juice. Physical activity was performed in the form of treadmill exercises with an intensity of $80-85 \%$ of the maximum heart rate (MHR= $220-$ age), frequency 3 times a week, duration $30 \mathrm{~min}$, for 28 days.

RESULTS: The results show that the increase in red blood cells and hemoglobin after intervention in PA+RDF group is higher than in the PA group, but based on statistic test, there is no significant difference to increase in red blood cells and hemoglobin between the two groups $(p>0.05)$.

CONCLUSION: The physical activity and red dragon fruit can prevent the decrease of red blood cells and hemoglobin in trained people.

\section{Introduction}

Physical activity is a life activity that aims to improve the quality of life, welfare, and human dignity. Physical activity can affect various aspects of life such as psychological, social, economic, cultural, political, and biological functions. One of the biological function of physical activity is a modulator with a wide spectrum of influence and can occur at various levels of function. The influence of physical activity on biological functions can be a positive influence that is improving fitness and health degrees as well as negative influences that inhibit or interfere with health [1].

The cardiovascular system serves to ensure the supply of oxygen to the muscles that contract during physical activity. The main function of the red blood cells in exercise is to distribute $\mathrm{O}_{2}$ to tissues and bring $\mathrm{CO}_{2}$ back to the metabolically produced of lungs. Any rapid muscle contractions begin with anaerobic metabolism. Energy comes from solving adenosine triphosphate (ATP) with adenosine diphosphate (ADP) or adenosine monophosphate results and takes place in the mitochondria. The release of energy is accompanied by the increased flow of electrons in the mitochondrial respiration circuit resulting in the formation of reactive oxygen and the ATP formation efforts [2].

Physical activity tends to empty the ATP and increases the amount of ADP that will stimulate ADP catabolism and conversion of xanthine dehydrogenase into xanthine oxidase. This xanthene oxidase will form free radicals [3]. The ATP also stimulates the formation of nitric oxide (NO) endothelial and causes arteriolar vasodilation and increases blood flow to contracted muscles [4]

Physical fitness depends on hematological parameters such as red blood cells and hemoglobin. Hemoglobin is needed in adequate quantities in trained athletes, especially in endurance sports. The decreased red blood cell count and hemoglobin harm physical performance [5]. Exercise with heavy intensity causes a decrease in body fitness such as weakness after completion and then anemia can occur after exercise [6]. A considerable loss of iron during physical exercise can trigger symptoms of anemia, the high level of physical activity of a person, especially for an athlete 
will affect the level of nutritional needs, especially iron needs. The iron is necessary because a person who regularly exercises has a larger mass of red blood cells so that the amount of iron needed to form it will be more [7].

Anemia iron deficiency called sports anemia negatively affects one's exercise capacity and health status [5]. A decrease in the amount of body iron can occur in female and male athletes. There is a lot of misconception about iron deficiency anemia and exercise, so it is crucial to have an understanding of iron deficiency anemia that is relevant for exercise professionals to educate clients properly [8].

During exercise, the body will experience a decrease in blood flow to the digestive tract and can be reduced iron contained in hemoglobin in red blood cells. In strenuous physical exercise, the body will need more iron reserves. Experts call it the phenomenon of foot-strike hemolysis. The effects of this exercise are not enough to cause anemia, but the depletion effect of it overtime will make it a problem if the iron reserves are depleted [9]. Red blood cells and hemoglobin may increase or decrease depending on the intensity, frequency, duration, and type of exercise [10]. Other factors that affect the value of red blood cells and hemoglobin are physical activity, gender, age, nutrition, and environment [11].

The effects of antioxidant supplementation are not yet fully known whether the body's natural antioxidants that act as a defense system can overcome the increase in free radicals during physical exercise or whether additional supplements are needed [12]. The iron belongs to essential nutrients, which means that the body cannot produce it and must obtain it from food. However, if the body does not consume enough iron as needed, within a certain period, iron nutrient anemia may occur [13].

One of the foods that contain iron and has antioxidant potential is the red dragon fruit (Hylocereus polyrhizus) [14]. The purpose of this study was to find out the effect of physical activity and consumption of red dragon fruit on red blood cells and hemoglobin in trained people. given physical exercise and obtained a placebo; Group 2 (PA+RDF): A group was assigned physical activity and given red dragon fruit juice. Before the research begins, an explanation is given to prospective research subjects about the purpose and purpose of the study, as well as samples which are willing to participate in the class sign an informed consent or consent sheet. The experimental procedures and protocol according to the principles of the Declaration of Helsinki were approved by the Human Ethics Committee of the Faculty of Medicine of the University of Sumatera Utara with the number 59/KEP/USU/2020.

The preliminary data collection before the start of treadmill exercises is carried out venous blood retrieval by health analysts for hematology parameters examination. The subjects did not exercise or participate in sports activities for the 2 days before resting what took blood samples. The blood was taken from the antecubital vein to collect plasma using EDTA (ethylenediaminetetraacetic acid) or heparin as an anticoagulant. Physical activity was performed in the form of treadmill exercises with an intensity of $80-85 \%$ of the maximum heart rate $(\mathrm{MHR}=220-$ age $)$, frequency 3 times a week, duration $30 \mathrm{~min}$, for 28 days. The red dragon fruit juice with a dose of $2.8 \mathrm{~g} / \mathrm{kg}$ body weight is smoothed using a blender then added $70 \mathrm{ml}$ of water, given daily for 28 days. Immediately after the treadmill exercise at the end of the time, the research was again carried out venous blood retrieval by health analysts for the examination of hematology parameters. Hematology parameters examination is carried out in the Regional Health Laboratory of North Sumatra Province, Indonesia, using the hematology analyzer tool.

Then, the data were analyzed using paired t-test with $\alpha=0.05$, to test the influence of each variable and independent sample t-test with $\alpha=0.05$, to examine whether there is an influence of physical exercise and red dragon fruit juice on red blood cells and hemoglobin. The data obtained are then processed using statistical procedures using the help of SPSS program version 22 .

\section{Results}

\section{Methods}

This research method uses the preexperimental method with two-group pre-test and posttest group design who conducted this research in the Physical Laboratory of the Faculty of Sports Sciences, State University of Medan and Regional Health Laboratory of North Sumatra Province, Indonesia.

The subject of the study was 20 people, male, trained, divided into two groups randomly, each consisting of 10 people, namely, Group 1 (PA): A group that was
Table 1 shows that the mean of the red blood cells levels in the physical activity group in pre-test was $5.24 \mathrm{~m} / \mathrm{uL}$ and in the post-test was $5.46 \mathrm{~m} / \mathrm{uL}$. There was an average increase in red blood cells in the physical activity group of $4.03 \%$ but not significant $(p>0.05)$. The mean of the red blood cells levels in the physical activity and red dragon fruit group in pretest was $5.28 \mathrm{~m} / \mathrm{uL}$ and in the post-test was $5.52 \mathrm{~m} / \mathrm{uL}$. There was an average increase in red blood cells in the physical activity and red dragon fruit group of $4.35 \%$ but not significant $(p>0.05)$. 
Table 1: The mean of red blood cells and hemoglobin levels in physical activity group and physical activity+red dragon fruit group

\begin{tabular}{|c|c|c|c|}
\hline Variable & $\begin{array}{l}\text { PA group } \\
\text { Mean } \pm S D\end{array}$ & $\begin{array}{l}\text { PA+RDF group } \\
\text { Mean } \pm S D\end{array}$ & $p$ \\
\hline \multicolumn{4}{|l|}{ RBC (m/uL) } \\
\hline Pre-test & $5.24 \pm 0.302$ & $5.28 \pm 44.05$ & 0.781 \\
\hline Post-test & $5.46 \pm 0.488$ & $5.52 \pm 70.22$ & \\
\hline$\%$ increased & 4.03 & 4.35 & \\
\hline Paired t-test & 0.315 & 0.411 & \\
\hline \multicolumn{4}{|l|}{ HGB (g/dl) } \\
\hline Pre-test & $14.82 \pm 1.042$ & $14.80 \pm 1.394$ & \\
\hline Post-test & $15.11 \pm 1.155$ & $15.90 \pm 0.879$ & 0.115 \\
\hline$\%$ increased & 1.92 & 6.92 & \\
\hline Paired t-test & 0.602 & 0.97 & \\
\hline
\end{tabular}

The mean of the hemoglobin levels in the physical activity group in pre-test was $14.82 \mathrm{~g} / \mathrm{dl}$ and in the post-test was $15.11 \mathrm{~g} / \mathrm{dl}$. There was an average increase in hemoglobin in the physical activity group of $1.92 \%$ but not significant $(p>0.05)$. The mean of the hemoglobin levels in the physical activity and red dragon fruit group in pre-test was $14.80 \mathrm{~g} / \mathrm{dl}$ and in the post-test was $15.90 \mathrm{~g} / \mathrm{dl}$. There was an average increase in hemoglobin in the physical activity and red dragon fruit group of $6.92 \%$ but not significant $(p>0.05)$, as shown in Table 1 .

Figure 1 shows that the increase in red blood cells after intervention in PA+RDF group is higher than in PA group, but based on statistic test, there is no significant difference to increase in red blood cells between the two groups $(p=0.781 ; p>0.05)$.

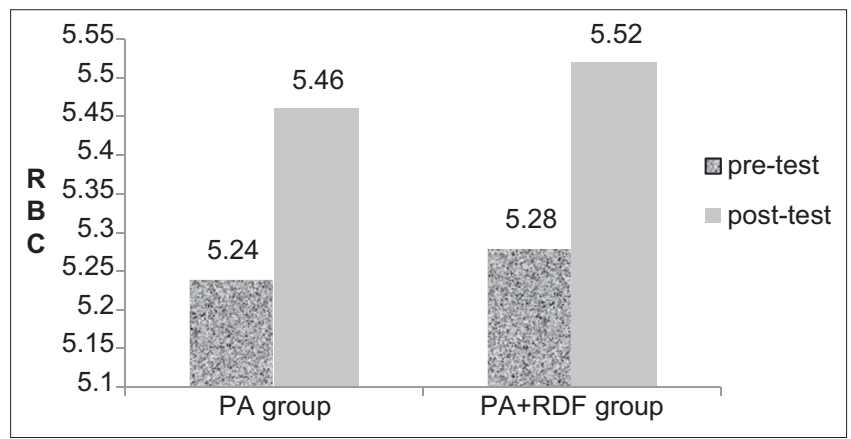

Figure 1: The red blood cell differences between physical activity group and physical activity+RDF group

Figure 2 shows that the increase in hemoglobin after intervention in PA+RDF group was higher than in PA group, but based on the statistic test, there was no significant difference to the increase in hemoglobin between the two groups $(p=0.115 ; p>0.05)$.

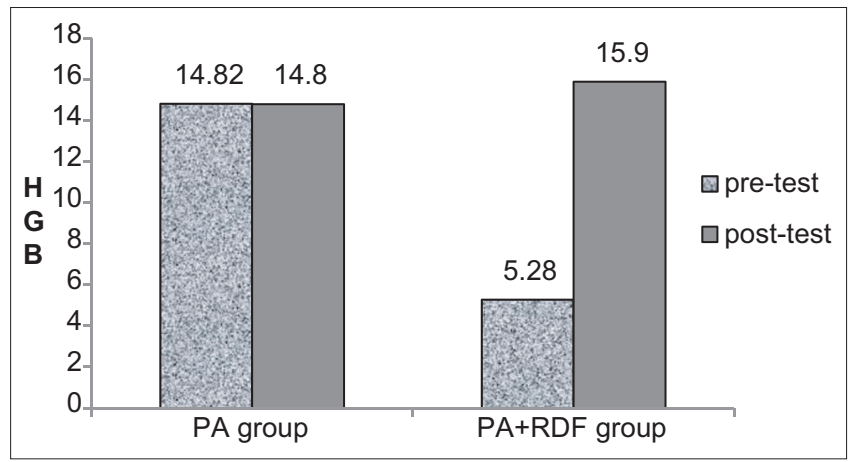

Figure 2: The hemoglobin differences between physical activity group and physical activity $+R D F$ group

\section{Discussion}

The results in this study were obtained that there was an increase in red blood cells and hemoglobin after intervention in both groups, but this increase was no significant difference. This is due to the increase in free radicals due to physical activity that affects the aerobic energy pathways in the mitochondria, causing fatigue [15]. The red blood cell and hemoglobin levels in PA+RDF group are higher than PA group because of the factor given red dragon fruit juice that contains flavonoids and polyphenols that have potential as antioxidants. The results showed that red dragon fruit in addition to antioxidants could also improve physical fitness [16].

The results showed that free radicals are one of the factors responsible for erythrocyte damage during and after physical exercise and can cause anemia often called "sports anemia" [13]. GomezCabrera et al. stated that oxidative damage due to physical activity could be prevented by optimizing nutrition, especially by increasing the antioxidant content in vegetables and fruits [17]. Research by Arifin et al. states that the administration of dragon fruit juice (H. polyrhizus) in female white mice can increase hemoglobin levels, the number of erythrocytes, and hematocrit percentage [18]

Physical activity stimulates erythropoiesis to increase $\mathrm{O}_{2}$ transport capacity. Newly formed cells also have an enhanced deformity that thickens the blood flow of muscles. The training also increased red blood cells 2.3 DPG, which further enhanced the $\mathrm{O}_{2}$ release from hemoglobin [19]. Regular exercise causes an increase in hematological parameters that positively affect exercise capacity [20], [21]. However, some researchers say that there is no indication that the hematological parameters change [22]. Athletes should be aware of the status of nutrients, especially their iron and the increased level of their energy expenditure, which determines the need for increased caloric intake to provide adequate foodstuffs and minerals (such as iron) for optimal physical function [23]. The results of the study by Cicek stated that there is a decrease in levels of red blood cells and hemoglobin in strenuous physical exercise compared to aerobic exercise [24].

Hemoglobin is needed in adequate quantities in trained athletes, especially in endurance sports, having decreased hematocrit, which is sometimes called sports anemia. This is not anemia in a clinical sense since athletes have a total increase in red blood cell mass and hemoglobin circulation relative to individuals who are not sedentary much. In the physical activity, there is an increase in skeletal muscle contraction in line with the increased need for $\mathrm{O}_{2}$ so that there is an increase in muscle blood flow by increasing cardiac output [25], [26]. In physical activity occurs the binding of the bloodstream, so that red blood cells as a mediator 
to produce Nitric oxide derivatives. Nitric oxide is a signaling molecule that causes vasodilation [19].

The mechanisms cause anemia after physical exercise can occur. One of them is the condition of anemia caused by hemolysis or the process of solving red blood cells due to mechanical pressure and oxidative stress conditions, where the amount of free radicals in the body increases during physical exercise. Based on the theory, that the breakdown of red blood cells tends to occur in old blood cells, but a considerable loss of iron during physical exercise can trigger symptoms of anemia [23].

During physical exercise, there is an increase in blood plasma, causing the blood to become more fluid, and the concentration of red blood cells decreases. As a result, red blood cells pumped by the heart throughout the body decrease in number, especially in muscle tissue. The high level of physical activity of a person, especially for an athlete, will affect the level of nutritional needs, especially the need for iron. Stored iron decreases through sweat excretion. Without enough iron, the body cannot produce enough hemoglobin for red blood cells. Iron is necessary because a person who regularly exercises has a more extensive period of red blood cells so that the amount of iron needed to form it will be more [19].

The red dragon fruit is a source of vitamins and minerals, which consists of Vitamin B1 reaches $0.3 \mathrm{mg} / 100 \mathrm{~g}$ of flesh. Red dragon fruit also contains phytochemicals that are good for body health such as flavonoids [27]. The Flavonoids contained in red dragon fruit is capable of directly capturing the superoxide and peroxynitrite. By capturing the superoxides, flavonoids enhance the bioavailability of nitric oxide and inhibit formation of peroxynitrite. Nitric oxide is a major molecule that results in local vasodilation. Flavonoids can also catch peroxynitrite that damages the endothelium, resulting in eventual better blood circulation in the coronary arteries [28].

\section{Conclusion}

The red dragon fruit has the potential as a source of iron and antioxidants, and physical activity improves physical fitness. The physical activity and red dragon fruit can prevent the decrease of red blood cells and hemoglobin in trained people.

\section{References}

1. Adam GM. Exercise Physiology, Laboratory Manual. New York: McGraw-Hill Companies Inc.; 2002.
2. Kelsey WF, Bloomer JR. Acute exercise and oxidative stress: A 30 year history. Dyn Med. 2009;8:1-25.

PMid:19144121

3. Chevion S, Molan DS, Heled Y, Shani Y, Regrev G, Abbou B, et al. Plasma antioxidant status and cell injury after severe physical exercise. Proc Nat Acad Sci U S A. 2003;100(9):511923. https://doi.org/10.1073/pnas.0831097100

PMid:12702774

4. Gonzalez-Alonso J, Olsen DB, Saltin B. Erythrocyte and the regu-lation of human skeletal muscle blood flow and oxygen delivery: Role of circulating ATP. Circ Res. 2002;91(11):104655. https://doi.org/10.1161/01.res.0000044939.73286.e2 PMid:12456491

5. Schumacher YO, Schmid A, GrathowhI D, Bultermann D, Berg A. Hematological indices and iron status in athletes of various sports and performances. Med Sci Sports Exerc. 2002;34(5):869-75. https://doi.org/10.1097/00005768-200205000-00022

PMid:11984308

6. Mairburl H. Red blood cells in sports: Effects of exercise and training on oxygen supply by red blood cells. Front Physiol. 2013;12(4):332. https://doi.org/10.3389/fphys.2013.00332 PMid:24273518

7. Weaver AM, Kravitz L. Understanding iron-deficiency anemia and sports anemia. IDEA Fitness J 2014;11(8):16-9.

8. Kong WN, Guofen G, Chang YZ. Hepcidin and sports anemia. Cell Biosci. 2014;4:19.

PMid:24731443

9. Clark SF. Iron deficiency anemia. Nutr Clin Pract. 2008;23(2):128-41.

PMid: 18390780

10. Belviranli M, Okudan N, Kabak B. The effects of acute highintensity interval training on hematological parameters in sedentary subjects. Med Sci. 2017;5(15):1-7. https://doi. org/10.3390/medsci5030015

PMid:29099031

11. Wardyn GG, Rennard SI, Brusnahan SK, McGuire TR, Carlson ML, Smith LM, et al. Effects of exercise on hematological parameters, circulating side population cells, and cytokines. Exp Hematol. 2008;36:216-22. https://doi.org/10.1016/j. exphem.2007.10.003

PMid:18206729

12. Clarkson PM, Thomson HS. Antioxidants: What role do they play in physical activity and health. Am J Clin Nutr. 2000;72(2):637s-46. https://doi.org/10.1093/ajcn/72.2.637s PMid:10919970

13. Senturk UK, Yalcin IO, Gunduz F, Kuru O, Meiselman HJ, Baskurt OK. Effect of antioxidant vitamin treatment on the time course of hematological and hemorheological alterations after an exhausting exercise episode in human subjects. $J$ Appl Physiol. 2005;98(4):1272-9. https://doi.org/10.1152/ japplphysiol.00875.2004 PMid:15579575

14. Rebecca OP, Boyce AN, Chandran S. Pigment identification and antioxidant properties of red dragon fruit (Hylocereus polyrhizus). Afr J Biotechnol. 2010;9(10):1450-4. https://doi. org/10.5897/ajb09.1603

15. Kendall BK, Eston RG. Exercise-induced muscle damage and the potential protective role of estrogen. Sports Med. 2002;32(2):10323. https://doi.org/10.2165/00007256-200232020-00003 PMid:11817996

16. Maigodaa TC, Sulaeman A, Setiawan B, Wibawan IW. Effects of red dragon fruits (Hylocereus polyrhizus) powder and swimming exercise on inflammation, oxidative stress markers, and physical fitness in male obesity rats (Sprague dawley). Int $\mathrm{J}$ 
Sci. 2016;25(1):123-41.

17. Gomez-Cabrera MC, Domenech E, Vina J. Moderate exercise is an antioxidant: Upregulation of antioxidant genes by training. Free Radic Biol Med. 2008;44(2):126-31. https://doi. org/10.1016/j.freeradbiomed.2007.02.001

PMid:18191748

18. Arifin H, Nofiza W, Elisma E. Pengaruh pemberian jus buah naga (Hylocereus undatus) terhadap jumlah hemoglobin, eritrosit dan hematokrit pada mencit putih betina. J Sains Teknol Farm. 2012;17(2):118-25. https://doi.org/10.31958/js.v9i2.748

19. Mairbäurl H. Red blood cells in sports: Effects of exercise and training on oxygen supply by red blood cells. Front Physiol. 2013;12(4):332. https://doi.org/10.3389/fphys.2013.00332 PMid:24273518

20. Duzova H, Karakoc Y, Gullu E, Gullu A, Koksa B, Esen B. The acute effects of single football match on whole blood viscosity and hematological variables in female soccer players. Biomed Res. 2016;27(4):1423-5.

21. Ceylan Hİ, Babayiğit İG, Saygın Ö. Examining of the effects of aerobic dance and step dance exercises on some hematological parameters and blood lipids. Int J Hum Sci. 2014;11(2):980-91. https://doi.org/10.14687/ijhs.v11i2.3077

22. Spiropoulos K, Trakada G. Hematologic and biochemical laboratory parameters before and after a marathon race. Lung.
2003;181(2):89-95. https://doi.org/10.1007/s00408-003-1009-y PMid:12953147

23. Ajmani RS, Fleg JL, Demehin AA, Wright JG, O'Connor F, Heim JM, et al. Oxidative stress and hemorheological changes induced by acute treadmill exercise. Clin Hemorheol Microcirc. 2003;28(1):29-40.

PMid: 12632010

24. Cicek $\mathrm{G}$. The effects of different exercise types on hematological parameters in sedentary women. J Educ Train Stud 2018;6(8):3374.

25. Laughlin MH, Davis MJ, Secher NH, van Lieshout JJ, ArceEsquivel AA, Simmons GH, et al. Peripheral circulation. Compr Physiol. 2012;2(1):321-447.

PMid:23728977

26. Uzun M. Kardiyovasküler sistem ve egzersiz. J Cardiovasc Nurs. 2016;7(2):48-53.

27. Rebecca OP, Zuliana R, Boyce AN, Chandran S. Determining pigment extraction efficiency and pigment stability of dragon fruit (Hylocereus polyrhizus). J Biol Sci. 2008;8(7):1174-80. https://doi.org/10.3923/jbs.2008.1174.1180

28. Akhlaghi M, Brian B. Mechanisms of flavonoid protection against myocardial ischemia-reperfusion injury. J Mol Cell Cardiol. 2009;46(3):309-17. https://doi.org/10.1016/j.yjmcc.2008.12.003 PMid:19133271 